\title{
Insulin-Like Growth Factor I: a Modulator of Erythropoiesis in Uraemic Patients?
}

\author{
P. Ureña ${ }^{1}$, A. Bonnardeaux ${ }^{1}, K_{\text {Kai-Uwe Eckardt }}^{2}$, A. Kurtz ${ }^{2}$ and T. B. Drüeke \\ ${ }^{1}$ Département de Néphrologie and INSERM U 90, Hópital Necker-Enfants Malades, Paris, France; ${ }^{2}$ Physiologisches \\ Institut der Universität Zürich, Zürich, Switzerland
}

\begin{abstract}
Anaemia is a feature almost invariably complicating chronic renal failure. Its pathophysiology is multifactorial but the most important cause is erythropoietin (Epo) deficiency. However, either no relation or even a weakly positive relation generally exists between serum immunoreactive (i) Epo and haematocrit values in uraemic anaemia, whereas in anaemias of non-renal origin the correlation is most often strongly negative. Recent evidence indicates that growth hormone also stimulates erythropoiesis. Moreover, late erythroid progenitor cells (CFU-E) require insulin and/or insulin-like growth factor I (IGF-I) for development in vitro. IGF-I has been shown to have a synergistic action with Epo. We have measured serum iEpo and IGF-I levels in 17 haemodialysis patients with severe hyperparathyroidism (mean \pm SEM serum iPTH, $988 \pm 88 \mathrm{pg} / \mathrm{ml}$ ). Mean age and duration of dialysis treatment were $46.1 \pm 3.4$ and $8.8 \pm 1.0$ years respectively. Mean haematocrit and haemoglobin values wer $28.1 \pm 1.7 \%$ and $9.39 \pm 0.54$ $\mathrm{g} / \mathrm{dl}$ respectively. Mean serum iEpo and IGF-I levels were $20.3 \pm 4.7 \mathrm{mU} / \mathrm{ml}$ and $320 \pm 20 \mathrm{ng} / \mathrm{ml}$ respectively (normal values for serum iEpo and IGF-I, $17.9 \pm 6 \mathrm{mU} /$ $\mathrm{ml}$ and $91 \pm 23 \mathrm{ng} / \mathrm{ml}$ respectively). We found that serum IGF-1 concentrations were well correlated with haematocrit values $(r=0.68, n=15, P<0.004)$ whereas serum iEpo values were not $(r=0.41, n=12, P=$ 0.18 ). IGF-I could therefore be an important factor
\end{abstract}

Correspondence and offprint requests to: Tilman B. Drieke, MD, Department of Nephrology, Hopital Necker, 161 rue de Sèvres, 75743 Paris Cedex 15, France. regulating erythropoiesis in uraemic patients, at least when associated with severe hyperparathyroidism.

Key words: Insulin-like growth factor I; IGF-I; Erythropoietin; Anaemia; Hyperparathyroidism; Uraemia; Haemodialysis

\section{Introduction}

Anaemia of moderate to severe degree is a feature which almost invariably complicates chronic renal failure (CRF). Its pathophysiology is multifactorial. Several possible mechanisms have been described and include decreased erythropoietin (Epo) production, shortened red blood cell survival, retained inhibitors or toxic substances that interfere with erythroid marrow function, iron and folate deficiency, and blood loss. However, the most important cause of end-stage renal disease anaemia clearly appears to be relative Epo deficiency [1].

Secondary hyperparathyroidism in haemodialysis patients has also been considered as a likely factor predisposing to anaemia $[2,3]$. However, no correlation has been found between serum intact parathyroid hormone (iPTH) $[4,5]$ or serum immunoreactive Epo [6-8] and the severity of the anaemia in uraemic patients. Indirect evidence suggests that high serum iPTH values could be implicated in the impaired production of Epo encountered in these patients [9]. Recent findings 
demonstrate that serum iEpo values increase after parathyroidectomy (PTx) in dialysis patients with secondary hyperparathyroidism $[9,10]$. It has also been shown that anaemia could improve after PTx in many of these patients [11-13]. In addition, hyperparathyroidism has been associated with a relative resistance to the effects of recombinant human erythropoietin ( $\mathrm{rHuEpo}$ ) treatment in dialysis patients [1].

If haematocrit does not correlate with serum Epo, other erythropoietic factors should be considered. A major candidate for this is growth hormone $(\mathrm{GH})$ and its cellular mediator, insulin-like growth factor I (IGF-I). There is growing evidence indicating that GH stimulates erythropoiesis in vitro and in vivo independently from Epo $[14,15]$. Moreover, erythroid colonyforming units (CFU-E) require direct interaction with IGF-I and/or insulin for development [16]. It has also been suggested that insulin and IGF-II stimulate DNA synthesis and proliferation of CFU-E additively through a similar receptor or postreceptor system [17]. IGF-I has a supportive effect on the proliferation and differentiation of erythroid precursors and its action is synergistic to that of Epo [18]. Furthermore, a recent animal study has shown that during accelerated growth, IGF-I but not Epo correlates with the increase in red cell mass [19].

The purpose of the present study was to investigate whether serum IGF-I values were correlated with the degree of anaemia in dialysis patients with severe secondary hyperparathyroidism.

\section{Methods}

\section{Patients}

Seventeen consecutive patients with chronic renal failure and severe secondary hyperparathyroidism (11 men and 6 women) who were admitted to the Nephrology Department of the Necker Hospital, Paris participated in the study. Their mean ( \pm SEM) age was $46.1 \pm 3.5$ years and their mean ( \pm SEM) duration of dialysis was $8.9 \pm 1.0$ years. Underlying nephropathies were as follows: nephrosclerosis 2 , chronic interstitial nephritis 3 , polycystic kidney disease 3 , chronic glomerulonephritis 3 , hereditary nephropathy 2 , and unknown 4 . No patient was receiving rHuEpo, steroids, or androgens. None had malnutrition or hepatic dysfunction. However, the nutritional status and in particular the dietary habits of the patients have not been precisely evaluated. All patients underwent maintenance haemodialysis thrice weekly and were dialysed with their usual dialysis membranes, either of synthetic or cellulosic type. Acetate or bicarbonate dialysates were used and dialysate calcium concentration was $1.75 \mathrm{mmol} /$ litre.

\section{Serum Biochemistries}

Blood samples were obtained after a 12-h fast before a dialysis session. Plasma calcium was measured using atomic absorption spectrometry and plasma phosphorus using a Technicon Auto Analyzer. Plasma alkaline phosphatase activity was measured by an automated method (normal range: 30-90 IU/hitre). Serum intact PTH (iPTH) was measured using a commercial radioimmunometric assay for intact human PTH (Allegro Intact PTH, Nichols Institute, San Juan Capistrano, Calif, USA). The normal range was $10-65 \mathrm{pg} / \mathrm{ml}$. Plasma aluminium ( $\mathrm{Al}$ ) was determined using atomic absorption spectrometry with a graphite oven.

Serum insulin-like growth factor I (IGF-I) was determined after an acid-ethanol extraction as described by Daughaday et al [20], using a radioimmunoassay method (RIA) employing a rabbit antihuman IGF-I antiserum (insulin-like growth factor I/somatomedin C reagent pack for RIA, Amersham, International plc., Amersham, UK; normal range, 53-120 ng/ml; mean \pm SEM, $91.9 \pm 6.4 \mathrm{ng} / \mathrm{ml} ; n=13)$. Serum iEpo concentrations were determined by radioimmunoassay as described elsewhere [21]. Normal values in healthy adults with this assay are between 11 and $31 \mathrm{mU} / \mathrm{ml}(95 \%$ confidence interval; mean, $17.9 \pm 6 \mathrm{mU} / \mathrm{ml}, n=84$ ).

\section{Statistical Analysis}

Results have been expressed as means \pm SEM. The significance of the magnitude of correlation coefficients between biochemical values was assessed by linear regression analysis.

\section{Results}

Mean \pm SEM concentrations of haemoglobin, haematocrit, and reticulocytes were $9.3 \pm 0.5 \mathrm{~g} / \mathrm{dl}(n=16), 28.6$ $\pm 1.8 \%(n=15)$, and $52900 \pm 7385 / \mathrm{mm}^{3}(n=10)$ respectively. Marked secondary hyperparathyroidism was present in all patients, with serum iPTH levels and plasma alkaline phosphatase activities of $988 \pm 88 \mathrm{pg} / \mathrm{ml}$ $(n=17)$ and $461 \pm 85$ IU/litre $(n=17)$ respectively. Mean serum iEpo and IGF-I values were $20.3 \pm 4.7$ $\mathrm{mU} / \mathrm{ml}(n=13)$ and $320 \pm 26 \mathrm{ng} / \mathrm{ml}(n=17)$ respectively. Total plasma calcium, phosphate, and aluminium concentrations were $2.62 \pm 0.06 \mathrm{mmol} /$ litre $(n=17)$, $2.12 \pm 0.13 \mathrm{mmol} /$ litre $(n=17)$, and $1.9 \pm 0.2 \mu \mathrm{mol} /$ litre $(n=16)$ respectively. Serum iron and ferritin concentrations were $16.8 \pm 4.0 \mu \mathrm{mol} /$ litre $(n=15)$ and $274 \pm$ $114 \mathrm{ng} / \mathrm{ml}(n=15)$ respectively.

We found a significant linear correlation between serum IGF-I and haematocrit values as shown in Fig. 1. 


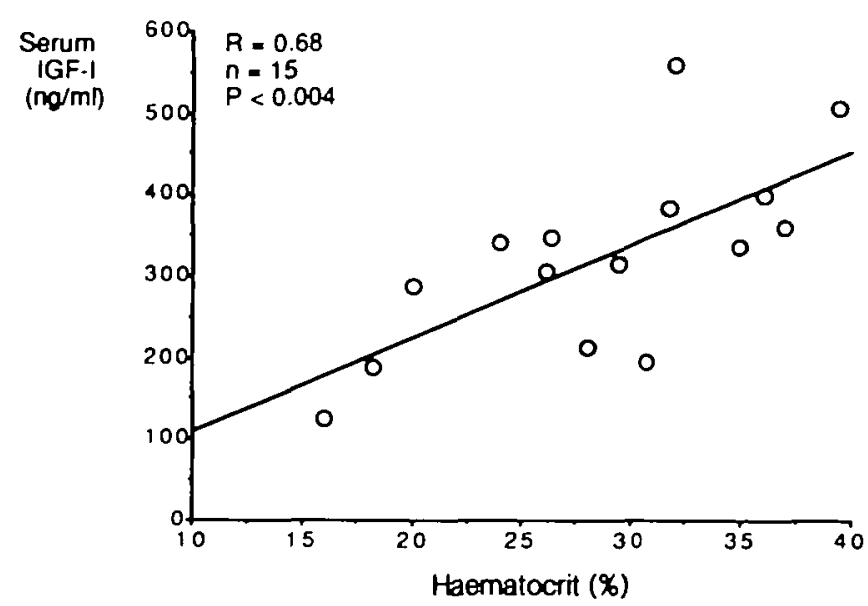

Fig. 1. Relationship between serum immunoreactive insulin-like growth factor I (IGF-I) and haematocrit.

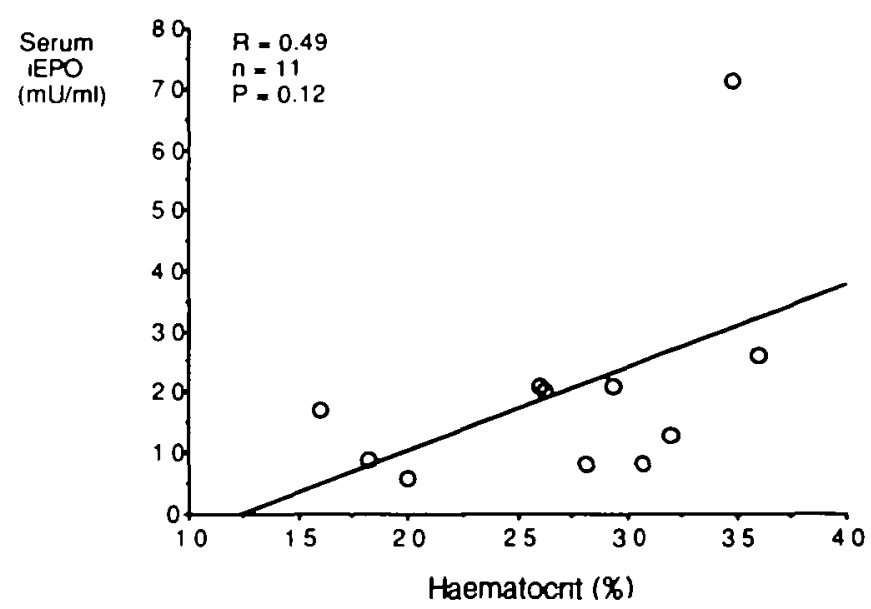

Fig. 2. Absence of a significant relationship between serum immunoreactive erythropoietin ( $\mathrm{Epo}$ ) and haematocrit.

By contrast, serum iEpo values were not correlated with haematocrit values (Fig. 2). No correlations were found between serum iPTH, iEpo and IGF-I or between serum iPTH and haematocrit. In addition, no correlation existed between IGF-I and the other biochemical parameters measured.

\section{Discussion}

In the present study we found that in an anaemic dialysis patient population with overt secondary hyperparathyroidism, not receiving rHuEpo treatment, serum IGF-I concentrations were positively correlated with haematocrit values. In contrast, no correlation was found between serum iEpo and haematocrit values.

In uraemic patients, serum iEpo values are known to be inappropriately normal or reduced in relation to the degree of anaemia and to correlate rather poorly with haematocrit [6-9]. Numerous other factors have been suggested to play a role in the anaemia of such patients including PTH excess. Several hypotheses have been proposed to explain the part played by secondary hyperparathyroidism, including a direct inhibitory effect of elevated serum iPTH on erythropoiesis and/or Epo activity [2], osteitis fibrosa with medullary fibrosis $[3,11,12]$, hyperphosphataemia with secondary increases in red blood cell glycolytic rate, adenosine triphosphate production and 2,3-DPG formation, causing a right shift of the haemoglobin/oxygen dissociation curve and better tissue oxygenation leading to reduced Epo production [22], and finally, a possible hypercalcaemia-related decrease in Epo release [23]. However, as stated previously, no correlation could be demonstrated between serum iPTH or iEpo values [4-8] and the degree of anaemia in uraemic patients with severe hyperparathyroidism. Moreover, only the degree of marrow fibrosis appeared to predict at least partially the correction of anaemia in response to PTx $[3,12]$. Nevertheless, it has been suggested recently that Epo production might improve after PTx since serum iEpo may considerably increase in at least some of the patients $[9,10]$. This could also explain the amelioration of the anaemia after correction of the hyperparathyroid state [9].

Factors other than Epo probably play a role in regulating erythropoiesis, including insulin-like growth factors (IGFs). IGFs are known serum peptides which are structurally related to insulin, and IGF-I is secreted by the liver in response to $\mathrm{GH}$ secretion. They have mitogenic as well as insulin-like activities and are thought to mediate $\mathrm{GH}$ action at the tissue level $[24,25]$. IGF-I is a small molecule of $7649 \mathrm{Da}$ and is bound to high-molecular-weight protein carriers of 40000 to $15000 \mathrm{Da}$. A certain degree of variability has been reported for serum IGF-I concentrations in uraemic patients [26-28], possibly due to methodological problems of IGF-I measurement and to the presence of plasma IGF-I binding proteins [28-30]. The results of our study, using a radioimmunoassay after acid-ethanol extraction, are in accordance with those of Andress et al [31] who found increased levels of serum IGF-I in uraemic hyperparathyroid patients.

Recently, serum IGF-I has been suggested as a marker of bone formation as well as of nutritional status in haemodialysis patients $[31,32]$. In addition, a slight improvement of anaemia and increased serum IGF-I concentrations were found after the administration of recombinant human $\mathrm{GH}$ to uraemic children on renal replacement therapy [33], and the occurrence of anaemia has been observed after the administration of a $\mathrm{GH}$ and IGF-I antagonist, namely somatostatin [34]. Theoretically, it is probable that IGF-I is implicated in the regulation of erythropoiesis in man. Two pieces of 
evidence support this hypothesis. First, IGF-I is required for CFU-E development $[14-16,35,36]$ and has a supportive effect on the proliferation and differentiation of erythroid precursors, in synergy with Epo [18]. Second, serum IGF-I but not serum iEpo levels, correlate with erythropoiesis during accelerated growth in rats [19].

However, to the best of our knowiedge, a relationship between serum IGF-I and anaemia has not been described in uraemic patients. It has been reported that a peptide of approximately $8000 \mathrm{Da}$ which was isolated from an anephric subject, was capable of regulating late erythropoiesis [37]. The $\mathrm{N}$-terminal sequence of this peptide has recently been shown to be identical to that of IGF-I by Congote et al [38] who suggested that IGF-I could replace erythropoietin as a stimulator of erythropoiesis in some patients with anaemia and renal failure. Similarly, Buemi et al proposed that this peptide could be responsible for the faster and more marked response to rHuEpo observed in anephric patients [39]. It is therefore tempting to speculate that IGF-I could play an important part in the erythropoiesis of uraemic patients with anaemia.

The positive correlation between IGF-I and haematocrit values had a coefficient of only 0.68 . This could be partly due to the action of other erythroid colonystimulating hormones such as Epo but also to a decreased IGF-I activity in uraemic serum secondary to the accumulation of a low-molecular-weight inhibitor normally cleared by the kidney $[29,31]$. The latter could lead to a decreased tissue sensitivity to IGF-I. A similar mechanism of end-organ resistance to $\mathrm{GH}$ has been proposed to explain growth retardation in uraemia despite elevated serum GH levels [40].

In summary, we have found that immunoreactive serum IGF-I but not iEpo values directly correlated with haematocrit in haemodialysis patients with severe secondary hyperparathyroidism. IGF-1 could be an important factor regulating erythropoiesis in uraemic patients. Further studies are needed to characterise this correlation and possible interactions with the nutritional status and other variables in order to define the precise role of IGF-I in the anaemia of uraemic patients with and without secondary hyperparathyroidism.

\section{References}

1. Eschbach JW. The anemia of chronic renal failure. Pathophysiology and the effects of recombinant erythropoietin. Kidney Int 1989; 35: 134-148

2. Meytes D, Bogin E, Ma A, Dukes PP, Massry SG. Effects of parathyroid hormone on erythropoiesis. J Clin Invest 1981; 67: $1263-1269$

3. Potasman I, Better OS. The role of secondary hyperparathyroidism in the anemia of chronic rerai failure. Nephron 1983; 33: 229 231
4. Caro J, Brown S, Miller O, Murray T, Erslev AJ. Erythropoietin levels in uremic nephric and anephric patients. $J$ Lab Clin Med 1979; 93: 449-458

5. McGonigle RJS, Wallin JD, Husserl F et al. Potential role of perathyroid hormone as an intibitor of erythropoiesis in the anemia of renal failure. J Lab Clin Hed 1984; 104: 1016-1026

6. MeGorigle RJS, Wallin JD, Shadduck RK, Fisher JW. Enthropoietin deficiency and inhibition of erythropoiesis in rerai' insufficiency. Kidney Int 1984; 25: 437-444

7. Chandra M. Clemons G, MeVicar MI. Relatior of serum eythropoietin levels to renal excretory function: Evidence for lowered set point for erythropoietin production in chronic renal failure. $J$ Pediatr 1988; 113: 1015-1021

8. Walle AJ, Wong GY, Clemons GK, Garcia JF, Niedermayer W. Erythropoietin-hematocrit feedback circuit in the anemia of endstage renal disease. Kidney Int 1987; 31: 1205-1209

9. Ureña P, Eckard K-U, Sarfati E et al. Serum erythropoietin and erythropoiesis in primary and secondary hyperparathyroidism: Effect of parathyroidectomy. Nephron, in press

10. Washio $M$, Iseki $K, O h Y$ et al. Transient increase of serum erythropoietin (EPO) after sub-total parathyroidectomy (PTX) in patients (PTS) with chronic hemodialysis (HD). Kidney Int 1990; 37: 285

11. Zingraff J, Drüeke T, Marie P, Man NK, Jungers P, Bordier P. Anemia and secondary hyperparathyroidism. Arch Intern Med 1978; 138: 1650-1652

12. Barbour GL. Effect of parathyroidectomy on anemia in chronic renal failure. Arch Intern Med 1979; 139: 889-891

13. Shasha SM, Better OS, Winaver J, Chaimovitz C, Barzilai A, Erlik D. Improvement in the anemia of hemodialyzed patients following subtotal parathyroidectomy. Evidences for the role of secondary hyperparathyroidism in the etiology of the anemia of chronic renal failure. Isr J Med Sci 1978; 14: 328-332

14. Golde DW. Growth hormone: species-specific stimulation of erythropoiesis in vitro. Science 1977; 196: 1112-1113

15. Kurtz A, Zapf J, Eckhardt K-U, Clemons G, Froesch ER, Bauer C. Insulin-like growth factor I stimulates erythropoiesis in hypophysectomized rats. Proc Natl Acad Sci USA 1988; 85: 7825-7829

16. Sawada K, Krantz SB, Dessypris EN, Koury ST, Sawyer ST. Human colony-forming units-erythroid do not require accessory cells, but do require interaction with insulin-like growth factor I and/or insulin for erythroid development. J Clin Invest 1989; 83: 1701-1709

17. Dainiak N, Kreczko S. Interactions of insulin, insulin-like growth factor II, and platelet-derived growth factor in erythropoietic culture. $J$ Clin Invest 1985; 76: 1237-1242

18. Akahane K, Tojo A, Urabe A, Takaku F. Pure erythropoietic colony and burst formations in serum-free culture, and their enhancement by insulin-like growth factor I. Exp Hematol 1987; 15: 797-802

19. Kurtz A, Matter R, Eckardt K-U, Zapf J. Erythropoiesis, serum erythropoietin, and IGF-I in rats during accelerated growth. Acta Endocrinol 1990; 122: 323-328

20. Daughaday WH, Mariz IK, Blethen SL. Inhibition of access of bound somatomedin to receptor and immunobinding sites: a comparison of radioreceptor and radioimmunoassay of somatomedin in native and acid-ethanol-extracted serum. $J$ Clin Endocrinol Metab 1980; 51: 781-788

21. Eckardt K-U, Kurtz A, Hirth P, Scigalla P, Wieczorek L, Bauer C. Evaluation of the stability of human erythropoietin in samples for radioimmunoassay. Klin Wochenschr 1988; 66: 242-245

22. Lichtman MA, Miller DR, Abel V, Kearney E, Lockwond C. Erythrocyte glycolysis, 2,3-diphosphoglycerate and adenosine triphosphate concentration in uremic subjects: relationship to extracellular phosphate concentration. J Lab Clin Med 1970; 76: 267-269

23. McGonigle RJS, Brookin' J, Pegram BL. Fisher JW. Enhanced erythropoietin production by calcium entry blockers in rats exposed to hypoxia. J Pharmacol Exp Ther 1987; 241: $428-432$

24. Phillips LS, Vassilopoulou-Sellin R. Somatomedin's I. N Engl J Med 1980; 302: 371-380

25. Phillips LS, Vassilopou!ou-Se!lin R. Somatomedin's II. $N$ Engl J Med 1980; 302: 438-446 
26. Enberg G, Hall K. Immunoreactive IGF-II in serum of healthy subjects and patients with growth hormone disturbances and uremia. Acta Endocrinol 1984; 107: 164-170

27. Goldberg A, Trivedi B, Delmez J, Harter H, Daughaday WH. Uremia reduces insulin-like growth factor-I, increases insulin-like growth factor-II and modifies their serum protein binding. $J \mathrm{Clin}$ Endocrinol Merab 1982; 55: 1040-1045

28. Powell DR, Rosenfeld RG, Baker BK, Liu F, Hintz RL. Serum somatomedin levels in adults with chronic renal failure: The importance of measuring insulin-like growth factor-I (IGF-I) and IGF-II in acid-chromatographed uremic serum. J Clin Endocrnol Metab 1986; 63: 1186-1192

29. Phillips LS, Fusco AC, Untermann TG, Del Greco F. Somatomedin inhibitor in uremia. J Clin Endocrinol Metab 1984; 59: 764 772

30. Hardouin S, Gourmelen M, Noguiez P et al. Molecular forms of serum insulin-lıke growth factors (IGF)-binding proteins in man: relationships with growth hormone and IGFs and physiological significance. J Clin Endocrinol Metab 1989; 69: 1291-1301

31. Andress DL, Pandian MR, Endres DB, Kopp JB. Plasma insulinlike growth factors and bone formation in uremic hyperparathyroidism. Kidney Int 1989; 36: 471-477

32. Jacob V, Le Carpentier JE, Salzano et al. IGF-I, a marker of undernutrition in hemodialysis patients. Am J Clin Nutr 1990; 52 : $39-44$

33. Tönshoff B, Mehis O, Heinrich U, Blum WF, Ranke MB,
Schauer A. Growth-stimulating effects of recombinant human growth hormone in children with end-stage renal disease. $J$ Pediatr 1990; 116: 561-566

34. Fossati P, Verier-Nine O, Dewailly D et al. Effets de la sandostatine administrée en injections répetées, à doses croissantes, dans le traitement de 40 acromégales. Annales Endocrinol (Paris) 1988; 49: 323-330

35. Kurtz A, Jelkmann W, Bauer C. A new candidate for the regulation of erythropoiesis. FEBS Lett 1982; 149: 105-108

36. Kurtz A, Hărtl W, Jelkmann W, Zapf J, Bauer C. Activity in fetal bovine serum that stimulates erythroid colony formating in fetal mouse livers is IGF-1. $J$ Clin Invest 1985; 76: 1643-1648

37. Brox AG, Congote F, Fafard J, Fauser AA. Identification and characterization of an 8-kd peptide stimulating late erythropoietin. Exp Hematol 1989; 17: 769-773

38. Congote LF, Bron A, Lin FK, Lu HS, Fauser AA. The $N$. terminal sequence of the major erythropoietic factor of an anephric patient is identical to insulin-like growth factor I. J Clin Endocrinol Metab 1991; 72: 727-729

39. Buemi $M$, Allegra A, Aloisi C, Giacobbe MS, Frisina N. Different answer to recombinant human erythropoietin in anephric and non-anephric haemodialyzed patients. Nephron 1990; 56: 218-219

40. Mehls O, Ritz E, Hunziker EB, Eggli P, Heinrich U, Zapf J. Improvement of growth and food utilization by human recombinant growth hormone in uremia. Kidney $I n t$ 1988; 33: 45-52

Received for publication 2.1.91

Accepted in revised form $18.6 .9 I$ 